\title{
The Principle of Rahn Utilization in Non-Cash Transactions of Gold at Islamic Banks
}

\author{
Moh. Ali \\ University of Jember, Indonesia \\ alifirmansyah2013@gmail.com \\ Siska Hidayatur Rahma \\ University of Jember, Indonesia \\ siska.ishall@gmail.com
}

\begin{abstract}
Non-cash gold transactions are one type of service provided by Islamic banks. Non-cash gold transactions using contracts as a binder between Islamic banks and customers. The contract consists of either murabahah and rahn contracts, as outlined in a Proof of Ownership of Gold (SBKE). In the rahn contract, there is a stipulation that gold, which is the object of non-cash, is used as collateral for Islamic banks. This study aims to analyze the validity and suitability of the rahn contract, and future concepts of non-cash, gold trading transactions using the principle of benefit. The results showed that the rahn contract does not meet contract validity standards detailed in KHES (Compilation of Economic Sharia Law) Article 2l, because there were provisions that contradicted Article 18 (1) H of Law No. 8 of 1998 on Consumer Protection. Rahn in non-cash gold transactions is generally the same as pawning; however, in non-cash gold transactions, there is an initial transaction in the form of murabahah. Also, there is a guarantee used no longer in the form of gold but in the form of proof of gold ownership, otherwise known as a gold certificate, as provided for in MUI DSN fatwa No. 68 of 2008 concerning tasjily.
\end{abstract}

KEYWORDS: Non-Cash Gold Transactions, Rahn Contracts, Principle of Utility.

Copyright $\odot 2019$ by Author(s)

This work is licensed under a Creative Commons Attribution-ShareAlike 4.0 International License. All writings published in this journal are personal views of the authors and do not represent the views of this journal and the author's affiliated institutions.

\section{HOW TO CITE:}

Ali, Moh \& Siska Hidayatur Rahma. "The Principle of Rahn Utilization in Non-Cash Transactions of Gold at Islamic Banks" (2019) 6:3 Lentera Hukum 445-462.

Submitted: January 16, 2019 Revised: March 07, 2019 Accepted: October 22, 2019 


\section{INTRODUCTION}

Islamic banks have different operational activities with conventional banks guided by sharia principles. Sharia principles are the essential characteristic of Islamic banks: Islamic principles always guide every transaction. As described in Article 1 (12) of the Sharia Banking Act, sharia principles are Islamic legal principles based on a fatwa, or non-binding, yet formal legal opinion, issued by an institution authorized to make legal interpretations based on Islam. To support themselves, Islamic banks carry out business activities in the form of financing, deposits, and other services. One such service is buying and selling gold in cash. Non-cash gold transactions are a murabahah financing product and pawn service. The pawn service, or rahn, is a type of agreement to hold an item as a debt-dependent. ${ }^{l}$ Rahn in Arabic is al-tsubut wa al-dawwan, meaning permanent and eternal. ${ }^{2}$ This word also refers to something material. Other perceptions suggest that Rahn is an agreement to hand over assets as placeholders for a created debt.

Non-cash gold transactions have a legal basis that functions to protect the parties during the transaction. The basis of gold installments or non-cash gold trading is the National Sharia Fatwa Council of the Indonesian Ulema Council fatwa No. 77/DSNMUI/V/2010 concerning the Sale and Purchase of Gold in Cash. The fatwa explained that non-cash gold transactions are permissible (ja'iz) as long as gold (the object of buying and selling) is not a means of payment. Islamic banks partaking in the sale and purchase of gold using cash are bound in a via the Proof of Gold Ownership (SBKE). The SBKE contains a murabahah agreement financing gold ownership and rahn pawn contract. Murabahah and rahn are integral and inseparable parts of the SKBE. ${ }^{3}$ The SBKE contract is a standard, unilateral contract issued by an Islamic bank. Several principles must manifest in each standard contract, as specified in Article 18 of Law No. 10 of 1998 concerning Consumer Protection (Consumer Protection Act). In the rahn contract, there is a provision stating that gold that is the object of cash sale and purchase may be used as collateral for Islamic banks as long as the gold has not been paid off or as long as the gold is still subject to the installment payment process.

Rahn is not only practiced based on sharia principles. In non-Islamic contexts, rahn is known as pawn. When connected to the sale and purchase of gold in cash, rahn and pawn have both shared, and distinctive characteristics Rahn requires a contract, or murabahah, at the beginning of the loan and the object of collateral is gold, whereas pawn can utilize collateral other than gold. According to the authors of this study, this difference is quite significant, because it necessitates further study on the validity of rahn. The majority of the Indonesian population is Muslim, but Indonesia is not an

$1 \quad$ M. Sulaeman Jajuli, Kepastian Hukum Gadai Tanah dalam Islam (Yogyakarta: Deepublish, 2015) at 98.

Syafe'i Rahmat, Konsep Gadai dalam Fikih: Antara Nilai Sosial dan Komersial (1995) at 59.

Bank Syariah Mandiri. Surat Bukti Kepemilikan Emas (Banyuwangi: Bank Syariah Mandiri,2016) at 1. 
Islamic state. There are still people in Indonesia who adhere to other religions or use other principles. Therefore there is a need for conformity between rahn and non-sharia pawn.

This study asks three research questions. First, does the rahn contract in the sale and purchase of gold using cash that meet contract validity standards? Second, is the concept of Rahn in the sale and purchase of non-cash gold in Islamic banks conformed with the concept of Rahn Syariah and the concept of non-Islamic pawns? Third, how do non-cash gold transactions without rahn comply with the principle of expediency?

For the context of this research, it is necessary to outline some of the previous studies discussing similar legal issues. Research on the sale and purchase of gold using cash is the focus of previous research entitled "Analysis of Islamic Law Against the Implementation of Gold Installments with the Murabahah and Rahn Contracts (Study at Mandiri Syariah Bank, Madiun Branch)," conducted in 2017 at the State Islamic Institute Ponorogo's Sharia Economics Master Program by Sri Puji Rohmiatun. The study stated that customers at the MSB branch in Madiun were required to fulfill criteria, after which MSB conveyed the price of gold, advances, monthly installments, margins, and information regarding defaults to customers.

Margins were determined unilaterally by MSB, and customers did not have bargaining rights. If a customer agreed to these conditions, they would sign a form containing the murabahah and rahn contracts. Murabahah here is a contract for buying and selling gold between MSB (the bank represents the customer) and the gold seller. The rahn contract here is a process where, after buying and selling gold, gold will be used as collateral at BSM during the installment process. The gold will be handed over to customers once the customer has paid the gold installments. Contracts on gold installments that use both murabahah and rahn do not qualify as multi-contracts because the murabahah and rahn are implemented consecutively rather than simultaneously.

This study's research method intends to answer questions by examining cases against legal rules, principles, and doctrines. This study uses a type of normative legal research focused on examining the application of norms that exist in active, positive law ${ }^{4}$ The study's normative analysis is divided into two categories: (1) the statutory approach and (2) the conceptual approach. The statutory approach examines regulations related to the legal issues put forward, ${ }^{5}$ in this case, regarding the rahn in the sale and purchase of gold using cash at Islamic banks. The conceptual approach examines views and doctrines developed in the science of law to address the question. ${ }^{6}$

Johnny Ibrahim, Teori dan Metodologi Penelitian Hukum Normatif (Malang: Banyumedia, 2008) at 295.

Dyah Ochtorina Susanti and A'an Efendi, Penelitian Hukum Legal Research (Jakarta: Sinar Grafika,2014) at 1-2.

6 Johnny Ibrahim, supra note 4 at 306. 


\section{THE VALIDITY OF THE CONTRACT IN THE GOLD OWNERSHIP FINANCING AGREEMENT}

\section{A. Non-Cash Gold Transactions in Islamic Law}

Article 1 (13) of the Islamic Banking Act explains the agreement containing the rights and obligations of Islamic banks and other parties under sharia principles. Adiwarman A. Karim explains that the meaning of a contract is not always a legal relationship that binds two parties. ${ }^{7}$ The contract can be interpreted as wa'ad, a unilateral statement from one person to another about anything. ${ }^{89}$ In another sense, wa'ad is a promise made by someone expressing their desire to do something to benefit others, either through action or speech. ${ }^{10} \mathrm{Wa}$ ad only binds the party which must fulfill its promises to another, yet the other party is not bound or obliged to fulfill the promise. ${ }^{11}$ Financing at Islamic banks is an example in which customers file a wa'ad. Wa'ad becomes a contract when the Islamic bank approves financing proposed by the customer. It can conclude that when talking about Islamic banks and positive law in Indonesia, the latter involves both sharia and secular contexts. ${ }^{12}$ As a result, positive law possesses two different meanings. ${ }^{13}$

Every contract made by the parties shall meet in harmony contract and term contracts. ${ }^{14}$ Pillars and contract terms establish the contract's validity. Article 28 (3) of the Supreme Court Regulation No. 2 of 2008 on the Compilation Law of Islamic Economics (hereinafter referred to KHES) explained that if a contract does not fulfill certain pillars or terms, it can be canceled. KHES Article 22 identifies four contract pillars: the subject, the object, lafadz, and objectives. The following definitions are provided for the contract pillars:

1. The subject of the contract is the party or parties implementing the agreement directly involved in the contract. ${ }^{15}$

2. The object is the agreement between a person or a party and another person or party which must satisfy the principle of benefit, meaning the object must benefit both parties. The principle of benefit is essential because the absence of benefit, or harm (mafsadat), is forbidden in Islam. ${ }^{16}$

\footnotetext{
Adiwarman Karim, Bank Islam Analisis Fiqih dan Keuangan (Jakarta: Raja Grafindo Persada, 2016) at 484. Ibid. Undang-Undang Hukum Perdata. Thesis (Semarang: Magister Kenotariatan Universitas Diponegoro, 2012) at 36.

16 Gemala Dewi, Aspek-Aspek Hukum dalam Perbankan dan Perasuransian Syariah di Indonesia (Jakarta: Kencana, 2004) at 102.
} 
3. KHES Article 24 states that the contract object can be amwal, ${ }^{17}$ for example, regarding buying and selling goods with gold, the contract object is gold.

4. Akad contains consent (offer) and qabul (reception), based on Islamic principles outlined in a written agreement in which each party has certain rights and obligations. ${ }^{18}$

5. Contract purpose is related to validity; the contract must not conflict with syara' and "should be in line with the will of syara." 19

According to Islamic agreements, contract pillars are the fundamental elements of contracts. Therefore, harmony between contract pillars and execution is necessary. ${ }^{20}$ Parties must meet the contract requirements. Contract terms are derived from contract pillars. The terms of the contract consist of (1) parties who want to do akad must be competent; (2) contract objects can receive by the law of the contract; (3) akad held by contract parties must comply with sharia provisions, even if the party does not have the goods. Akad must comply with Islamic law and should provide benefits for all parties in contract. $^{21}$ The aforementioned contract terms are requirements that must be fulfilled in order for a contract agreement to be perfect. Fulfillment of pillars and terms make contracts binding. In Islam, purchase contracts are known as bai 'murabahah, an agreement of two or more parties in implementing the initial purchase price plus a profit.

\section{B. Contracts and Non-Cash Gold Transactions in the Civil Code}

As with trading, the daily practice of buying and selling using non-Islamic principles is also often practiced. R. Subekti argues the purchase is a binding agreement in which one of the parties and their bodies hands over property to the other party as payment for the difference between what was initially agreed and paid. ${ }^{22}$ Sale and purchase requires parties to implement the agreement, obtain their rights, and fulfill their obligations. Islamic law's akad is known in the non-Islamic Civil Code Article 1313 (hereinafter known as the Civil Code) as an act by which one or more parties binds themselves to one or more persons. According to R. Subekti, the agreement is an event where one party actively promises another or in which two people are pledged to carry something. ${ }^{23}$ Akad used in buying and selling gold does not involve cash yet generally involves the same document content. Each contract always contains the contract title, as well as the rights and obligations of each party. Additionally, the contract always

17 Article 1 Point 9 Compilation of Islamic Economics Law (KHES).

18 Irma and Suswinarno, Panduan Lengkap Hukum Praktis Populer Kiat-Kiat Cerdas, Mudah, dan Bijak Memahami Masalah Akad Syariah (Bandung: Kaifa, 2011) at 2.

19 Ibid.

20 Marilang, Hukum Perikatan: Perikatan yang Lahir dari Perjanjian (Makassar: Tim Indonesia Prime, 2017) at 174 .

21 Abdul Rahman Ghazaly, Fiqh Muamalat (Jakarta: Kencana, 2010) at 55.

22 R.Subekti, Hukum Perjanjian (Jakarta: Intermasa, 1987) at 122.

23 Ibid at 1. 
includes a clause regarding dispute settlement if the contract parties find some disagreement in contract fulfillment. The general difference between the contract and the agreement as a legal source is Islamic sharia principles and non-Islamic principles, respectively.

\section{Validity of Civil Code Contract Agreements for Non-Cash Gold Transactions in the Case of Bank Syariah}

According to KHES a valid contract is an agreement that fulfills the pillars and conditions detailed in the contract. Each contract in Islamic banking must comply with the provisions of the contract, as follows: ${ }^{24}$

a. Pillars consist of the seller, the buyer, the price, and the contract. In buying and selling gold without cash, terms of validity are as follows:

1) Customers applying for financing ownership of gold;

2) Islamic banks on the terms to obtain the buying and selling gold is not cash;

3) Customer agrees and meets all the requirements of Islamic banks, Islamic banks then purchasing gold with gold provisions are used as security for the repayment of financing gold purchase the customer subsequently signed an ownership Financing Gold Proof.

There are two forms of financing for gold ownership. The first form contains the customer's identity information; the period of buying and selling gold without cash; monthly installment amounts; gold prices at the time of purchase, which is quantified as the purchase price of gold plus a deposit and margin; the value of the loaned funds used by Islamic banks to finance customers for the purchase of gold; the purchase contract; the commencement date; date of commission for installments; margins for buying and selling gold without cash; advance money used for buying and selling gold without cash; the administrative costs of buying and selling gold without cash; and the expiration date of the last installment.

The second sheet contains a murabahah contract for financing gold ownership and pledging agreement ( $\mathrm{rahn}$ ). In addition to contract pillars, Islamic banks are expected to buy gold from sellers following customers' requests and prevailing gold prices; then, the customer is bound by the murabahah financing agreement and contract pawn gold ownership (rahn).

b. Terms of the contract consist of:

1) Goods and services must be lawful, gold buying and selling gold without cash under the DSN MUI Fatwa No. 77 / DSN-MUI / V / 2010 on Non-Cash Trade in Gold is permissible (ja'iz) for gold is neither a tool payment nor money.

2) The prices of goods and services must be clear. When customers apply to Islamic banks to own gold, Islamic banks will immediately check the prevailing gold

24 Muhammad Shafi Antonio. Bank Syariah From Theory To Practice (Jakarta: Gema Insani, 2001) at 29. 
price at the time and inform customers about the terms of payment and the result of buying and selling gold without cash.

3) Place of delivery must be clear when the purchase of gold has been settled. The customer will bring the place along with an ownership certificate and valid identifying document as stipulated in the murabahah contract financing provision.

4) Traded goods should already be in possession; gold as the contract object must be purchased in advance from gold sellers.

Pillars and conditions here are not the elements that make the contract invalid.

KHES Article 26 describes invalidating factors as follows:

1. Akad contrary to the provisions of Shari'a law. The contract is executed between two or more parties through the consent process and granted under the provisions of Islamic law. ${ }^{25}$ In the banking world, customers often dare not violate the contents of the agreement because of its roots in positive law. ${ }^{26}$ Thus, the contract in Islamic banks should be based on extant laws.

2. Akad contrary to the legislation in force. Akad contrary to legislation is that which violates contract legislation. Using standard contracts to arrange non-cash gold transactions is permissible by the Act, but this standard contract should not be contrary to Article 18 paragraph (1) of Law No. 8 of 1998. Article 18 outlines the following parameters for contracts:

a. Contracts must declare the transfer of responsibility between business enterprises;

b. Contracts must state that businesses are entitled to reject the handover of the goods bought by consumers;

c. Contracts must state that businesses are entitled to reject the handover of money paid for the goods and/or services purchased by consumers;

d. Contracts must include customers' authorization form of business representation unilateral actions related to goods purchased by consumers in installments;

e. Contracts must provide for proof of loss of goods or service use;

f. Contracts should entitle businesses to reduce the benefits of services or wealth of consumers;

g. Contracts must state consumer liability to regulation in the form of new rules, additional, secondary and/or advanced conversions made unilaterally by businesses in the future consumption of services purchased; and

h. Contracts must state that the consumer authorizes the business to loading encumbrance, lien, or security interests against goods purchased by consumers in installments.

When linked to the contract on proof of gold ownership, pawn or rahn agreements are contrary to Article 18 (1) h, in which provisions state that in order to 
guarantee the debt of customers, the customer must hand over the collateral without coercion. In contrast, Article 18(1) g states that for items purchased in installments, customers can not be burdened with security rights. If there are such provisions, the contract will be null and void.

\section{THE SUITABILITY OF RAHN IN NON-CASH GOLD TRANSACTIONS AND NON-SHARIA PAWNS}

\section{A. Rahn System}

Rahn is the practice of holding. ${ }^{27}$ Rahn is based on the Qur'an, the Sunnah and opinions of scholars agree that rahn is permissible, but does not require a guarantee. As a guarantee only serves to maintain the confidence of the loan. KHES identifies the following pillars for rahn: (a) rahin must be capable of law; (b) murtahin rahin equals must have the skills to be legal; (c) marhun must have value and be transferable According to KHES Article 342, marhun may not have to belong to rahin; (d) marhun bih can be augmented by also adding another marhun; (e) akad made verbally, in writing or by gestures. $^{28}$

The legal basis for rahn is the National Sharia Board Fatwa Council of Ulama Indonesia and DSNMUI Fatwa No. 25/DSNMUI/III/2002, DSN-MUI No. 25/DSNMUI/III/2002 concerning the legal divisions ( $r a h n)$, murtahin rights, obligations and about marhun rahin submitted to murtahin rahin. ${ }^{29}$ The fatwa also articulates the following criteria: marhun can be sold, marhun can take the form of property, marhun should be beneficial, marhun must have value, marhun cannot be ham or pork, marhun can be seen clearly and definitely, marhun must belong to the rahin, marhun must stand alone.

All the above requirements must be met. The above requirements are related to each other, such that compliance will be easier. Besides DSN-MUI No. 25/DSNMUI/III/2002, Fatwa No. 26/DSN-MUI/III/2002 concerning the Use of Gold as Marhun (hereinafter referred to DSN-MUI fatwa No. 26/DSN-MUI/III/2002). DSN-MUI Fatwa No. 26/DSN-MUI/III/2002 allows for gold as marhun in rahn, but moving objects other than gold can also be used as marhun. Still, this exception is limited to moving objects. Objects that do not move cannot be marhun in rahn exchanges because of a different form of assignment. ${ }^{30}$ Moving objects other than gold that can be used as marhun include motorcycles, cars, or other goods that move because of their nature. Moving goods can be made subject to the trade law by exchange of proof of ownership. Proof of ownership can be made marhun under MUI No.68/DSN-MUI/III/2008 (hereinafter the

27 Ibid at 128.

28 Article 346 KHES

29 Muhammad Syafi'i Antonio. Bank Syariah: Wacana Ulama dan Cendekiawan (Jakarta: Bank Indonesia and Tazkia Institute, 2001) at 21.

30 Yusuf Adi Diktat Wibowo. Course: Law Benda (Jember: Universitas Jember, 2012) at 3. 
DSN MUI Fatwa No. 68/DSN-MUI/III/2008). However, the fatwa explicitly states that ownership of a physical object is not itself an object. In the positive law, concept is thus known with the imposition of a security interest in the form of a fiduciary. ${ }^{31}$

In the connection of law, this discussion leads to a relationship between one or more parties. One party within this relationship is entitled to see the other party's obligations fulfilled. ${ }^{32}$ Rahn is likewise characterized by rights and obligations belonging to rahin and murtahin, respectively, that must be fulfilled by each of the parties. According to KHES, the rights and obligations of rahin and murtahin are as follows:

1. Murtahin entitled to withhold marhun to settle maroon rahin bih (Article 343 paragraph (1) KHES);

2. If rahin died then murtahin entitled to payment for marhun bih of the other party (the party that obtained dependents of rahin) (Article 343 paragraph (2) KHES);

3. Rahin must still pay marhun bih to murtahin despite no marhun (Article 344 KHES);

4. If rahin has settled marhun bih then rahin entitled to demand marhun submitted to murtahin (Article 345 KHES);

5. Marhun can be lent to third parties by agreement rahin and murtahin (Article 356 KHES);

6. if marhun di- (Rahn) -kan on with no permission from the lack murtahin or rahin the contract (Rahn) is void (Article 354 KHES);

7. Marhun cannot be sold without the permission murtahin rahin (Article 355 KHES);

8. Marhun can be used with the permission rahin murtahin (Article $357 \mathrm{KHES}$ ).

The fulfillment of the above rights and obligations do not end rahn. When the debt has been paid off, marhun will be handed back to rahin, indicating that rahn has expired..$^{33}$ Rahn may also be terminated if rahin defaults to murtahin, so marhun is sold to pay off the debt. ${ }^{34}$ KHES articles 347 and 348 states that rahn will not end due to the death of rahin or murtahin, because the heirs may continue the contract.

\section{B. Conventional Pawn System}

Pawn is a business activity that is a financial institution based on a conventional system that does not very much (Rahn). Pawn run by competent judicial body under the provisions of the Government Regulation No. 103 of 2000 on Public Company (Perum) Pawn (hereinafter referred to by Regulation No. 103 of 2000) on Pawnshop. In Article

31 Rachmadi Usman. Jaminan Fidusia Hukum Kebendaan (Jakarta: Raja Grafindo Persada,2012) at 283.

32 R. Subekti, supra note 22 at 1.

33 Rachmat Syafe'i. Fiqh Muammalah (Bandung: Pustaka Setia, 2001) at 178.

34 Ibid. 
8a PP No. 103 of 2000 stipulates the functions of pawnshops was lent in the form of a pledge. In the Dutch language is pledge, and in the English language is a pawn. ${ }^{35}$ According to Article 1150 of the Civil Code Pawn is a right acquired by the creditor on the debtor's moveable goods are handed over as collateral for the debt of the debtor and entitles the creditor to take the settlement of accounts receivable from the debtor's other creditors (right preferences will); except for the implementation of the decision on the demands of ownership or control of cost of sales and cost of goods for pawn ongoing rescue. ${ }^{36}$

According to Salim $\mathrm{HS}^{37}$ pledge is an agreement made by the creditor and the debtor, where the debtor to ensure debt repayment to creditors deliver the goods moving. According to Kashmir ${ }^{38}$ pawn business is an activity of certain parties pledge over his valuables to borrow some money to the other party, and pledged goods will be reimbursed per the agreement of both parties. It can be concluded that the pledge is an act where there is a party that delivered the goods pawn called the pledgor, and there are those who receive goods pawn called receiver lien where the pledgor ensure their belongings to the recipient pawn in order to borrow money, and the pledgor will reimburse the item per the agreement of the pledgor and the recipient pawn.

The definition above shows that the pledge is not a pledge, but a principal agreement is an agreement accesoir (additional), and debts are necessarily agreements. ${ }^{39}$ The above definition also indicates that there are several elements: first lien, pledge subject is the recipient pawn and the pledgor; The second object of pledge which move goods belonging to the pledgor; Third, the authority of the recipient pawn in selling the collateral when the pledgor is unable to settle its debt to the recipient pawn. ${ }^{40}$

This authority relating to the rights and obligations of recipients pledge and the pledgor. Rights of lien receiver outlined in Article 1155 of the Civil Code of the principal, interest and term pledge. ${ }^{41}$ In addition, if the pawner has matured but unable to pay the installments or pay the debt, then the recipient pawn is entitled to sell by auction of goods belonging to the pledgor pawn. ${ }^{42}$ Sales of goods pawn can be made in a way that usually occurs and prevalent in public. ${ }^{43}$ If after pawning goods sold and there

\footnotetext{
35 Salim HS. Perkembangan Hukum Jaminan Fidusia di Indonesia (Jakarta: Raja Grafindo Persada, 2016) at 33.

36 Ibid at 33-34.

37 Ibid at 34.

38 Kasmir, Bank dan Lembaga Keuangan Lainnya (Medan: PPS USU, 2014) at 262.

39 Salim HS, supra note 35 at 34-35.

40 Ibid at 35 .

41 Ibid at 47.

42 Ibid at 52.

43 Ibid.
} 
are excess proceeds from the sale of goods pawn goods to repay the excess shall be submitted to the pledgor. ${ }^{44}$

Pawn ends if the pawner pay off debts to the recipient pawn. While the receiver lien obligations as set out in Article 1154, 1156 and 1157 of the Civil Code shall maintain recipient pawn goods; recipients pledge not eligible to become the owner of the pawn goods even if the pledgor does not implement obligations but not to the promise; if the pawn goods must be transported with the knowledge of the pledgor; in case of depreciation of goods due to negligence recipient pawn then the receiver should be responsible for it. ${ }^{45}$ Pledgor also the recipient should have the right to pledge, the pledgor form right to receive money from the goods pawned; If the debt, interest and other costs have been paid off then entitled to pledge goods; if tort right to demand the court to sell the pawn to pawn repayment of dependents to the recipient. ${ }^{46}$ While the obligation pledgor is pawned, goods must be delivered to the recipient pledge; pay all expenses including payments to recipients pledge; pay other costs incurred recipients pledge to maintain or salvage goods pawned. ${ }^{47}$

Mortgage institutions in conducting their business activities are not only oriented in the pawn business only. The same with Islamic banks have various kinds of other business activities in order to support the operations of the Islamic bank. Other business activities carried on by mortgage institutions are: (a) providing loans with fiduciary; (b) serving care services; (c) certification services for precious metals and precious stones; (d) providing a gold shop units; (e) managing the gold jewelry industry; (f) various other efforts to support the above activities. ${ }^{48}$ In further study, it can be concluded that the mortgage institutions are not only oriented to channel funds to the community. Pawnshops also offer services where the gold installment submission procedure is similar to that found in Islamic banks. Thus, Islamic banks are not the only financial institutions that provide gold purchases in installments because pawn shops are also running the business activities of this kind.

\section{The Conformity Rahn Non-Cash Transaction of Goldin Islamic Bank and Conventional Pawn}

A description of the system ( $r a h n)$ with a conventional mortgage system above shows that the difference between rahn on trade in gold is not cash and services which run the Islamic financial institution and run pawn pawnshop. However, in addition to the differences, there are also some similarities between concepts of rahn on trade in gold is not cash, such as concepts of rahn in sharia and the concept of non-sharia pawns. The equation is that this element of the rahn and pawn the civil concept is the same as their

44 Ibid.

45 Ibid at $47-48$.

46 Ibid at 48 .

47 Ibid.

48 Ibid at 37. 
rahin (pledgor) and murtahin (receiver mortgage), marhun (Goods pawned), marhun bih (Debt) and Contract (agreement used to bind the parties). If the customer cannot pay the installments to be paid every month then the collateral (marhun) has been given the pledgor (rahin) to the recipient pawn (murtahin) can be sold as a substitute for debt (marhun bih) under the remaining amount rahin marhun bih. Then if there is leftover money from the sale marhun the money is returned to rahin proficiency to the costs incurred when selling marhun.

While the difference of rahn on trade in gold is not cash, and concepts of rahn in sharia, as well as the concept of non-sharia pledge is as follows. The original transaction in non-cash transaction of gold is not cash there are two acquisition as murabaha and rahn whereas rahn with this concept is rahn and ijara, as well as the pledge to the concept of civil use of debts and liens. Objectives of rahn on trade in gold is not cash as a means to get the gold in the form of precious metals installments. Objectives of rahn in Islamic banks and objectives lien on mortgage institutions are alike to get almarhun bih (loans) to hand over al-marhun (guarantee).

Type of contract or agreement Type agreement on trade in gold is not cash is murabaha sale and purchase agreement and pledge agreement. Furthermore, covenants on rahn with this concept is an agreement of rahn and ijara. While the agreement used in pawn in pawnshops is the agreement of debts as a principal agreement and pledge agreement as additional agreements, type marhun guarantees on trade in gold is not cash is gold that becomes the object of the murabaha. Although gold has not paid off, gold here can be the object of this collateral under the provisions of Article 1131 of the Civil Code which explains that all goods to move or not to move the existing and there will be an individual who has a debt can be used as repayment of the debt owed. It is also under the principle of expediency is in debt owed parties do not have to have a guarantee that currently exists but can also ensure that no items will be in the future.

Moreover, marhun on rahn in with this concept is moving goods can be a form of gold or precious metal jewelry and other moveable goods that qualify for use as marhun and proof of ownership of an item. While pawn in a pawnshop guarantees on goods moving either tangible or intangible. ${ }^{49}$ Tangible moving objects are objects whose position transferred as an example is a motorcycle, gold, and cars. ${ }^{50}$ While moving intangible objects are objects that are not included physical form such as the right to harvest on an object. ${ }^{51}$

Proof of ownership of gold trade in gold is not cash is SBKE; this letter is used to take the gold when gold has paid off. Proof of ownership al-marhun in Islamic banks is a letter that explains the gold content that would be used collateral, but the nature of

\footnotetext{
49 Ibid at 37.

50 Ibid at 37-38.

5l Ibid at 38 .
} 
this letter is not required due to the absence of this letter of gold to be used Islamic banks will accept al-marhun. ${ }^{52}$ Moreover, in proof of ownership in Islamic banks, here can be the object of al-marhun and goods remain in possession of rahin. Pawn in pawnshops, when about to pawn gold at pawnshops as well as gold in Islamic banks that do not need to bring a letter that explains the levels of gold as collateral but the other his thing when going to pawn a motor vehicle in the pawnshop, when will mortgaging motor vehicles must bring BPKB and if BPKB nothing can replace it with vehicle registration. ${ }^{53}$

In non-cash transactions of gold is not allowed for the accretion marhun. Unless the trade in gold is not cash has been paid off. Then customers can repurchase a new precious metal with a new contract as well. With this concept allowed the accretion marhun. Likewise with the lien based on the concept of civil safety guarantees and debt accretion. Financial institutions were running Financial institutions that run the sale and the purchase of gold is not cash is certain Islamic banks and mortgage institutions. (Rahn) with sharia concept run by a financial institution that focuses on the sharia and sharia pawnshops. Pawn with civil concept run by mortgage institutions.

\section{CONCEPTS RAHN IN NON-CASH TRANSACTION OF GOLD AGAINST PRINCIPLE OF UTILIZATION}

\section{A. Principle Utilities}

The principle coined by Jeremy Bentham describes the expediency principle is the principle to achieve happiness even at the expense of other people's happiness for happiness. ${ }^{54}$ However, this principle is enhanced by Jeremy Bentham disciples of John Stuart Mill, according to John Stuart Mill's happiness was measured not by value but measured by the pleasures that provide benefits for many people, ${ }^{55}$ not only for those who plan such happiness. This happiness is achieved should not harm the other party. It concludes which derive happiness not only the people who planned happiness but also others involved in something that happens that causes such happiness.

Activity gold trading services are not cash-based DSN fatwa by the MUI No. 77/DSN/MUI/V/2010 on murabaha practice of buying and selling gold on gold is not cash customers do not automatically become a gold buyer. Unlike the case when the customer acts as rahin. Gold is used as marhun by rahin do not wholly-owned for the installment not paid off. However, Proof of Financing ownership Gold is on murabahah financing ownership of gold in the provision of point 5 states that in order to ensure

\footnotetext{
52 Interview with Diego Saba. Position: Customer Service. Bank Syariah Mandiri Banyuwangi (5 May 2018 at 1.30 P.M).

53 Interview with Ahmad Ritaudin. Position: Functional Officer. Pawnshops tiles (5 May 2018 at 09.00 A.M).

54 James Rachels, Moral Philosophy (Yogyakarta: Kanisius, 2004) at 170.

55 K. Bartens. Etika (Jakarta: Gramedia Pustaka, 2007) at 249-250.
} 
repayment orderly as it should be payable by the Islamic banks' customer, the customer offers gold financed by Islamic banks and under the provisions of Article 1131 of the Civil Code which explains that all property belonging to owe that already exist or will exist either moving or not moving items can be used as repayment of the debt owed when the debt in default.

Article 1131 of the Civil Code, but it has an inclusive sense that the word all movable and immovable belonging to the existing debt and will be able to be used as repayment of the debt owed. The 1131 article describes objects that can be used as an implicit debt repayment even if such objects can be confused with a guarantee of gold used on trade in gold is not cash. However, Article 1131 of the Civil Code is contrary to Article 18 paragraph (1) letter g of Act No. 8 1998. Article 18 paragraph (1) letter g of Law Number 8 of 1999 explains on goods that are in progress installments cannot be charged warranty rights. Furthermore, when it is done so under Article 18, paragraph (3) of Law No. 8 of 1998 declared null and voided the agreement complies with the provisions of Article 18 paragraph (1) letter g of Law No. 8 of 1998.

Based on the principle of lex specialis, which special rules override the general rule applicable so here is Article 18 paragraph 1 letter g Consumer Protection Act instead of Article 1131 of the Civil Code. Also, in the DSN MUI No. 77/DSN-MUI/V/2010 only explains the legal ability to carry out the trade-in gold is not cash. Here is not included in the process of purchasing and selling gold when used as collateral. Then it can be interpreted according to DSN MUI No. 77/DSN-MUI/V/2010 that gold cannot be used as collateral objects. Here is not included in the process of purchasing and selling gold when used as collateral. Then it can be interpreted according to DSN MUI No. 77/DSNMUI/V/2010 that gold cannot be used as collateral objects. Here is not included in the process of purchasing and selling gold when used as collateral. Then it can be interpreted according to DSN MUI No. 77/DSN-MUI/V/2010 that gold cannot be used as collateral objects.

Islamic law is recognized as the living law in which the Islamic legal norms accepted most of its existence in society. ${ }^{56}$ The purpose of Islamic law is to create welfare (maslahah) for all mankind, not only to Muslims. So true, maslahah is a principle that aims to provide benefits in the lurch parse and obtain facilities to all humankind without exception. ${ }^{57}$ Guarantees in sharia does not have the form of goods but could also be evidence of ownership over the goods. It is based on DSN MUI fatwa No. 68/DSN-MUI/III/2008, tasjily whose content is a form of guarantee of the goods on a debt based on the agreement rahin and murtahin submitted as collateral is not proof of ownership of the goods. When delivered as collateral is not proof of ownership of goods, then this is not contrary to Article 18 paragraph 1 letter $g$ of Law Number 8 of 1999 and DSN MUI No. 77/DSN-MUI/V/2010. Thus, tasjily in buying and selling gold is

56 Muhammad Abduh, Diktat Mata Kuliah: Sosial Institution (Lembaga Sosial)(1999).

57 Yasardin, Asas Kebebasan Berkontrak (Jakarta: Kencana, 2018) at 189. 
not cash is handed customers to the Islamic Bank, proof of ownership of gold bullion that is a certificate that explains the gold content.

The principle of utilitarianism aims to provide benefits to avoid losses. It is consistent with the concept of maqashid sharia is the perfect goodness and avoid the ugliness that is the purpose of sharia that benefit. ${ }^{58}$ Business activities in Islamic banks are always based on the contract or agreement that brings benefits to both parties. ${ }^{59}$ The purpose of executing the contract is welfare and mutually beneficial for both parties. The principle of mutual benefit following QS. Al-Maidah paragraph 2 which highlighted the obligation of mutual assistance in piety, and the prohibition for helping in sin and transgression. When connected to a tasjily in buying and selling gold is not cash between Islamic banks and customers, both sides will benefit from the product and services of Islamic banks regarding the buying and selling of gold is not cash demand of customers, and clients get gold following the procedure murabaha later tasjily.

\section{CONCLUSION}

The conclusion of this study is outlined in several points. First, the validity of akad rahn in Draft Agreement Financing ownership of Gold, in the contract their requirements valid contract being challenged is contrary to the law, namely proof of ownership of gold Terms of clause 1 contract lien contrary to Article 18 (1) item h Law No. 8 of 1999 on Consumer Protection states where this provision in order to ensure customer debt guarantee, the customer handed over the goods without any coercion. Moreover, Article 18 (1) point g Law No. 8 of 1999 on Consumer Protection stated that the goods purchased in installments customers could not be burdened with lien rights in this regard. If there are such provisions then under Article 18 (3) of Law No. 8 of 1999 on Consumer Protection, then the contract null and void. Second, the suitability of on sale buy gold in the non-cash system ( rahn) and conventional pawn, rahin and murtahin;

There is an agreement that the contract as the binder of rahin and murtahin; Their goods delivered as marhun. Third, the concept of the future of the sale and purchase of gold in non-cash is based on the objectives of Islamic law and the theory of utilitarianism, collateral to be used in non-cash transaction of gold is not cash does not have to be gold, but can also be proof of ownership of gold or gold certificates explaining the content of the gold. It is based on DSN MUI fatwa No. 68/DSNMUI/III/2008. Suggestions on this research that should include the Islamic banks in Indonesia that provide services business selling gold products is not good cash when making a contract must satisfy the validity of the contract regarding the agreement must not conflict with the legislation in force. The government should create a legal

\footnotetext{
58 Any Nugroho, Hukum Perbankan Syari'ah (Yogyakarta: Aswaja Pressindo, 2011) at 104.

59 Ibid at 109.
} 
framework that covers the gold that made marhun in non-cash transactions of gold is not cash in the bank in this type of product, and selling gold is not cash.

\section{REFERENCES}

Abdul Rahman Ghazaly. Fiqh Muamalat (Jakarta: Kencana, 2010).

Adiwarman Karim. Bank Islam: Analisis Fiqih dan Keuangan (Jakarta: Raja Grafindo Pesada, 2016).

Ahmad Ritaudin. Functional officer. Pegadaian Genteng. (2018), interview on 8 May 2018 at 09.00 PM. Bank Syariah Mandiri. 2016.

Any Nugroho. Hukum Perbankan Syari'ah (Yogyakarta: Aswaja Pressindo, 2011).

Diego Saba. Customer Service. Bank Syariah Mandiri Banyuwangi. (2018) Interview on 5 May 2018 at 1.30 PM.

Dyah Ochtorina Susanti and A'an Efendi. Penelitian Hukum: Legal Research (Jakarta: Sinar Grafika, 2014).

Frieda Husni Hasbullah. Hukum Kebendaan Perdata: Hak-Hak yang Memberi Kenikmatan (Jakarta: Ind-Hill-Co, 2005).

Gemala Dewi. Aspek-Aspek Hukum dalam Perbankan dan Perasuransian Syariah di Indonesia (Jakarta: Kencana, 2004).

Gita Rahmad Gunawan. 2012. Thesis: Perbandingan Akad Menurut Hukum Islam dan Perjanjian Menurut Kitab Undang-Undang Hukum Perdata.(2012) Semarang: Magister Kenotariatan Universitas Dipenogoro Semarang.

Irma and Suswinarno. Panduan Lengkap Hukum Praktis Populer Kiat-Kiat Cerdas, Mudah, dan Bijak Memahami Masalah Akad Syariah (Bandung: Kaifa, 2011).

James Rachels. Filsafat Moral (Yogyakarta: Kanisius, 2004).

Johny Ibrahim. Teori dan Metodologi Penelitian Hukum Normatif (Malang: Banyumedia, 2008).

K. Bartens. Etika (Jakarta: Gramedia Pustaka Utama, 2007).

Kashmir. Bank dan Lembaga Keuangan Lainnya (Jakarta: Raja Grafindo Persada, 2014).

Kharufah. 'Ala' al-Dīn.'Aqd al-Qardh fī al-Syarī'ah al-Islämiyyah wa al-Qānūn wa al-Wad'ī Dirāsah Muqāranah (Beirut:Muassasah Nawfal, 1982).

Marilang. Hukum Perikatan: Perikatan yang Lahir dari Perjanjian (Makassar: Indonesia Prime, 2017).

Muhammad Abduh. Diktat Mata Kuliah: Sosial Institution (Lembaga Sosial) (Medan, PPS USU, 1999).

Muhammad Syafi'I Antonio. Bank Syariah: Wacana Ulama dan Cendekiawan (Jakarta: Bank Indonesia dan Tazkia Institute, 2001).

Muhammad Syafi'I Antonio. Bank Syariah: Dari Teori ke Praktik. (Jakarta: Gema Insani, 2001). 
M. Sulaeman Jajuli, Kepastian Hukum Gadai Tanah dalam Islam (Yogyakarta: Deepublish, 2015).

R. Subekti. Hukum Perjanjian (Jakarta: PT. Intermasa, 1987).

Rachmad Syafei. Fiqih Muammalah (Bandung, Pustaka Setia, 2001).

Salim HS. Perkembangan Hukum Jaminan di Indonesia (Jakarta: PT. Raja Grafindo Persada, 2016).

Yasardin. Asas Kebebasan Berkontrak (Jakarta: Kencana, 2018).

Yusuf Adi Wibowo. Diktat Mata Kuliah: Hukum Benda (Jember: Fakultas Hukum Universitas Jember, 2012). 
462 | The Principle of Rahn Utilization in Non-Cash Transactions of Gold at Islamic Banks

This page is intentionally left blank 